A N N A L E S

UNIVER S T ATIS M A R A E C URIE-SKŁODOW K A

LUBLIN - POLONIA

VOL. XXXII, 1

SECTIO J

2019

Drohobych Ivan Franko State Pedagogical University

NADIYA ASHYTOK

ORCID ID: https://orcid.org/0000-0001-7447-5840

ashytni@ukr.net

\title{
Education Reform for Children with Peculiarities of Psychophysical Development in Contemporary Ukraine
}

Reforma edukacji dla dzieci niepełnosprawnych w nowoczesnej Ukrainie

\section{STRESZCZENIE}

W artykule przedstawiono analizę obecnego stanu i tendencji rozwoju edukacji włączającej na Ukrainie. Przedmiotem zainteresowania autora jest nie tylko polityka edukacyjna w kraju, ewolucja edukacji dla dzieci ze specyficznymi potrzebami w obszarze rozwoju psychofizycznego i istniejące doświadczenie integracyjnych praktyk edukacyjnych, lecz także problemy z organizacją edukacji narodowej na obecnym etapie jej rozwoju. Autor zwraca uwagę na możliwe zagrożenia w organizacji edukacji integracyjnej w tym państwie.

Słowa kluczowe: edukacja włączająca; dzieci ze specyficznymi potrzebami rozwojowymi; reforma edukacji; etapy rozwoju edukacji; instytucje edukacji włączającej

\section{SUMMARY}

The article offers an analysis of the current state and trends of inclusive education in Ukraine. The subject of attention of the author is not only the educational policy in the country, the evolution of education for persons with violations of physical, mental, intellectual development and sensory impairments and the existing experience of inclusive educational practice, but also problems with the organization of domestic education at the present stage of its development. The author draws attention to possible threats to the organization of inclusive education in this state.

Keywords: inclusive education; persons with violations of physical, mental, intellectual development and sensory impairments; educational reform; stages of development of education; institutes of inclusive education 


\section{INTRODUCTION}

In the history of mankind, the post-industrial stage of reforming is characterized by the leading role of science and education, through which the latest technologies are created and implemented in practice and, on the whole, the directions of social development are determined. In most of the developed countries distinctive reforms took place on the domestic grounds, which lasted gradually and systematically. However, there are reforms of the secondary type (this occurs, in particular, in Ukraine), which take place through borrowing experience from other countries. To ensure the success of reforms of this type, it is important to implement them gradually on the basis of national experience and comprehensive socio-political and socio-cultural restructuring in the state, provided that the concept of innovations is scientifically substantiated and supported by the participants. This also applies to the reformation of education for persons with violations of physical, mental, intellectual development and sensory impairments, which is intended to include these people in the general educational space of Ukraine on the basis of a humanistic approach according to their abilities and individual capabilities, taking into account knowledge about the specificity of their development, on the basis of respect for their dignity, needs, desires and interests. This process is a priority for the state educational policy in the country and takes place step-by-step, gradually. Certain periods can be identified in this process. Reforming of the education of persons with special educational needs has begun relatively recently, and therefore in the research on this process there is a certain number of urgent issues that are not adequately studied, which, in particular, include issues of distinguishing these periods and of taking into account national identity at the present stage of development of the national education.

\section{THE DEVELOPMENT OF SYSTEMS OF EDUCATION FOR SPECIAL CHILDREN IN UKRAINE AND ABROAD}

The formation and development of education for children with violations of physical, mental, intellectual development and sensory impairments has always been influenced by the specificity of the attitude of the society towards them. The society has gone up the path from hatred and aggression to tolerance and desire for partnership with them, recognition of the need for the integration of these individuals as full citizens in the society. In Ukraine, the development of education in the historical retrospect was studied by N. Holova (2012), V. Zasenko (2004), A. Kolupayeva (2009), V. Pokas (1999), M. Suprun (2005), M. Chepil (2014, pp. 296-302), M. Yarmachenko (1975) and others. Taking into account the specificity mentioned above, these and some other researchers distinguish five periods of development of education, the approximate boundaries of which 
are historical precedents of changing the attitude of the society and the state to people with developmental disabilities. In the evolution of the attitude towards these children in our lands, the same periods as in Western European countries are distinguished, but usually there is a considerable lag, as a result of which at the beginning of the $21^{\text {st }}$ century, Ukraine and Western Europe experience different periods of the evolution of relations and, accordingly, are at different stages of the development of systems of education for persons with special educational needs. Let us consider the characteristics of the periods of history of the formation and development of national systems of education for the children of the category in general terms (more information on this issue can be found in the works of A. Kolupaieva, M. Suprun, etc.) (Kolupaieva 2009; Suprun 2005).

The first period of evolution is a path from the aggression and intolerance to the awareness of the need to care for the disabled. An analysis of this period should start with the laws of child with a disability way from the opening of monastic refuges to the creation of secular shelters and hospitals and, finally, the emergence of a special secular shelter for blind military men (Bavaria, France, $12^{\text {th }}$ century). Gradually, on the European continent, the structure of care and medical help with its institutes (hospices, hospitals, shelters, asylum, leprosarium) was formed. Some of them were under the care of the church, while others were under the care of secular authorities.

If in Western Europe the first fact of care of the monarch for the persons with disabilities took place in the $12^{\text {th }}$ century, in our lands this happened only at the beginning of the $18^{\text {th }}$ century and was part of a complex of state reforms aimed at introducing Western European experience.

The second period of the evolution is a path from the awareness of the need to care for the persons with disabilities to the awareness of the possibility of teaching deaf and blind children; from shelters with the experience of individual training to the first special educational institutions. In the period from the $12^{\text {th }}$ to the $18^{\text {th }}$ centuries in Western European countries, systems of secular private and public shelters and homes for the elderly were created.

This period, which lasted six hundred years in Europe, began in our lands five centuries later, lasted one century and ended at about the same time as in the West, with precedents for the opening of the first domestic special schools for deaf and blind children at the beginning of the $19^{\text {th }}$ century. The first special educational institution (school for 12 deaf people) was opened under the direction of Empress Maria Feodorivna by Valentin Haüy, a French teacher of the blind, on October 14, 1806 in the town of Pavlovsk.

So, if the emergence of public special schools in Europe can be regarded as the result of political and economic reforms, secularization of public life, the opening of universities, the spread of secular schools, book printing, the rethinking of the rights of people with sensory impairments, the accumulation of successful 
experience of their individual learning, then the opening of domestic special schools occurred under the influence of the acquaintance of the monarchy with Western European experience and was conditioned by the desire to transfer it to the domestic grounds with the help of invited teachers.

The third period of the evolution is a path from the awareness of the possibility of teaching children with sensory impairments to the recognition of their right to education. This period covers the period from the $18^{\text {th }}$ to the beginning of the $20^{\text {th }}$ century in the West and is characterized by a change in the attitude towards the children of this category due to the adoption of a new, more humane and democratic view of their rights, as well as the introduction of general obligatory elementary education. The turning point in the state policy and public consciousness was prepared by the ideas of thinkers of the Renaissance and Enlightenment. In the analyzed period, for the first time, the status of the disabled has been changed by law: most European countries recognize their right to education. The key role was played by the French Declaration of the Rights of the Man and of the Citizen (1789). Since the beginning of the $20^{\text {th }}$ century, normative acts on the introduction of special education in Austria, England, Germany, Denmark, Italy and France have been adopted. It is during this period that national European systems of special education for three categories of children with hearing, visual and mental impairments appear. The rest of the children with marked impairments in the development are still under the care of church and secular charity.

For our country, the third period is special in the way that it covers the time of the revolutionary restructuring of the state and the society. The prerequisites for the formation of the national system of special education began to appear in one type of state - in a monarchical country, and to take their shape in the state of another type - in a socialist one. Since then, the national system of special education begins to differ from Western European systems, since it is built within the socialist state on another ideological basis, another understanding of human rights and freedoms. The end of the third period in the national education can be considered the years 1926-1930 - the time of legislating of the state system of special education for the three categories of children with special educational needs: the deaf, blind and mentally retarded and the introduction of elementary (four-year) education as a compulsory one for all citizens by the Central Executive Committee and the Council of People's Commissars "On General Compulsory Primary Education" (1930).

The fourth period of evolution marked a path from the awareness of the need for special education for particular categories of children with violations of physical, mental, intellectual development and sensory impairments to understanding the need for special education for all. For Western European countries, from the beginning of the $20^{\text {th }}$ century to the 1970 s, the improvement and differentiation of national education systems vertically and horizontally, the emergence of new 
types of special schools and new types of special education, the emergence of pre-school and post-school educational institutions and the expansion of types of educational institutions for persons with special educational needs took place. The vertical structure of education was based on the age-specific characteristics of pupils and levels of general education programs, and the horizontal structure was based on the psychophysical development of children and the peculiarities of their cognitive activity and the nature of the impairment. The beginning of this period in each country is determined by the time of adoption and ratification of the law on free general compulsory education and subsequent acts of compulsory education for children with violations of physical, mental, intellectual development and sensory impairments. The completion of this stage can be considered the adoption of the United Nations Declarations on the Rights of Mentally Retarded Persons (1971) and On the Rights of Persons with Disabilities (1975). Therefore, there are precedents for the closure of special schools and the transfer of their students to general education institutions; the opening of classes for children with deep mental retardation, who were previously considered incapable of learning.

The fourth period of evolution in our country falls on the Soviet period of history and differs from the similar period in Western Europe. The fundamental distinction between special education in the USSR is its qualification nature. A child with violations of physical, mental, intellectual development and sensory impairments, when entering an educational institution, had to master a state standard developed for the disabled students although in other terms and with the help of special methods of teaching. The general comprehensive secondary education for all categories of citizens was guaranteed by the Constitution of 1977. Domestic differentiated system of special education provided for the creation of a network of special educational institutions (school and preschool educational institutions, boarding schools, evening educational institutions for adults with some peculiarities of development). In the USSR, this stage is characterized by the development of the classification of children with violations in mental and physical development, the improvement of horizontal and vertical structures (the number of types of schools increases to 8, the number of types of special education reaches 15). Unlike Western European systems, Soviet special education was closed from the media.

The fifth period concentrates on the path from equal rights to equal opportunities; from "institutionalization" to integration. In the early 1970s, the Europeans managed to destroy the legislative foundations of the inequality of people with disabilities laid in ancient times. The beginning of the fifth period is the time when the UN Declarations on the Rights of the Mentally Retarded (1971) and the Law on the Rights of Persons with Disabilities (1975) were adopted. On the basis of these declarations, national anti-discrimination laws on persons with disabilities and special education are adopted: in Sweden - the Law on Assistance 
for Mentally Retarded, the Law on the Curriculum of the Main School (1980); in the UK - Education Acts (1981-1995); in the Netherlands - Provisional Law on Special Education and Secondary Special Education (1985). Since the 1970s, integration has become a leading trend, that is, the inclusion of children with special educational needs in the educational process, together with able-bodied persons. In the scientific community, on the one hand, integrative approaches to learning are supported, on the other hand, the results of the integration are exposed to critical comprehension, among the parents and specialists opponents of integration appear.

Specificity and complexity of the modern period of the development of the domestic educational system is that from 1991 to the present time in its boundaries there are divergent trends and approaches, some of which are oriented towards the improvement of the traditional system, others are oriented on the revolutionary transition to inclusive education, still others are oriented to develop a strategy for the evolutionary transition to a new educational system for special children.

The most justifiable is the evolutionary approach. Regarding the incompleteness of the previous stage and the distinction between the fourth developmental period and partly during the fifth one, Ukraine needs to develop its own model aimed at the maximum inclusion of children with violations of physical, mental, intellectual development into the inclusive space on the basis of the use of national and foreign experience in this field.

\section{REFORMING THE SYSTEM OF INSTITUTIONAL CARE AND UPBRINGING OF SPECIAL CHILDREN IN UKRAINE ON THE WAY OF THEIR INTEGRATION INTO SOCIETY}

The socio-political and socio-cultural processes that have been taking place in Ukraine since the end of the $20^{\text {th }}$ century to our time have had a significant impact on the development of education for children with special educational needs. This period can be roughly divided into three stages. The basis for such a division was the periodization of the history of the development of domestic education during the years of independence in the analytical study of the National Academy of Pedagogical Sciences of Ukraine (Nationalna dopovid ... 2016). This division into stages needs to be clarified. In particular, since in the first stage of the development, the educational system for special children with violations of physical, mental, intellectual development was based on a state-centered paradigm, the lower limit of the first stage, in our view, should be considered not the year 1991, as stated in the above-mentioned work, but the year 1971 when the UN Declaration on the Rights of the Mentally Retarded was adopted, because during this time, the educational system for children with special educational needs was invariably built on a state-centered basis. 
At the first stage, the right to education by all citizens, including children with violations of physical, mental, intellectual development and sensory impairments, has become legally recognized in the Laws "On Education" (1991, 1996), "On the Fundamentals of Social Protection of Disabled Persons in Ukraine" (1991), "On General Secondary Education" (1999), etc. However, in those years, public policy was predominantly compensatory, and appropriate educational measures were limited to insignificant financial assistance and the provision of individual services.

The second stage (2001-2010) of the development of the education system for people with special educational needs is characterized by intensification of the spontaneous integration of children with violations of physical, mental, intellectual development into general educational institutions, against the assertion of the positiveness of the foundations of the organization of inclusive education in democratic countries. At this stage, in the Ukrainian society, different discussions unfolded, such as discussions about the contradictions between the student's boarding school education and the ideas of equal rights of all citizens, innovative educational approaches with the recognition of the diversity of the student community, and the principles of full integration into society of people with peculiarities of psychophysical development. Since 2001, the program of the All-Ukrainian scientific and pedagogical experiment "Social Adaptation and Integration into the Society of Children with Peculiarities of Psychophysical Development by Organizing Their Education in General Educational Institutions" has been implemented, launched by the All-Ukrainian fund "Step by Step" under the scientific guidance of the Institute of Special Pedagogics of the National Academy of Sciences of Ukraine and under the organizational guidance of the Ministry of Education and Science of Ukraine. A significant role in the development of inclusive education was played by the introduction of amendments to the Law of Ukraine "On General Secondary Education" in 2010, according to which, general education institutions were able to create special and inclusive classes for the education of children with violations of physical, mental, intellectual development, which meant a state support for the inclusion. In the same year, the Ministry of Education and Science, Youth and Sports adopted "The Concept of the Development of Inclusive Education". For the first time, the concept included in the legislative field of Ukraine the definition of the inclusive education as an integrated process of ensuring equal access to quality education for children with special educational needs by organizing their studying in general educational institutions based on the application of personality-oriented teaching methods, taking into account the individual peculiarities of educational and cognitive activity of such children. The introduction of an additional post of assistant teacher in secondary schools was also envisaged. In the same year, the post of an assistant of a preschool education teacher was introduced into the Standard Staff 
Standards for Pre-School educational institutions by the Order of the Ministry of Education and Science of Ukraine "On Amendments to the Order of the Ministry of Education and Science of Ukraine" of 4 November 2010.

The third stage (2011 - to this day) is characterized by optimization of special educational institutions with the further deinstitutionalisation of education for children with violations of physical, mental, intellectual development and the spread of the inclusive education in Ukraine. In particular, the optimization represents a significant reduction of the network of special educational institutions against the background of the growth of the total number of children with disabilities (by $0.5 \%$ ) and a decrease of more than 1.5 times in the number of pupils with special needs from such institutions.

At this stage, practically all education links for this category of people were subjected to the changes related to the introduction of the inclusive education. A large number of normative and legislative acts regulating these changes were adopted. In particular, in order to regulate the inclusive general education, the Resolution of the Cabinet of Ministers of Ukraine "On Approval of the Procedure for the Organization of Inclusive Education in General Education Institutions" (2011), the Order of the Ministry of Education and Science "On Approval of the Regulations on the Individual Form of Education in General Educational Institutions" (2016), the Resolution of the Cabinet of Ministers of Ukraine "On Amendments to the Procedure for the Organization of Inclusive Education in General Education Institutions" (2017) were adopted.

On the basis of scientific and theoretical analysis and the definition of conceptual approaches, a new State standard of primary education for children with special educational needs was developed in Ukraine, which was subsequently approved by the Cabinet of Ministers of Ukraine "On Approval of the State Standard of Primary General Education for Children with Special Educational Needs" (2013). Subsequently, the contingent of elementary school pupils increased by the Order of the Ministry of Education and Science of Ukraine "On Approval of the Standard Curriculum for Children with Intellectual Disorders of Moderate and Severe Degree (Primary School)" (2017).

Significant changes occurred in the process of upbringing children with special needs in preschool establishments (in groups). By the Resolution of the Cabinet of Ministers of Ukraine "On the Amendments to the Regulation on Pre-School Institution" (2015), the establishment of inclusive groups in preschool educational institutions was introduced, and by the Order of the Ministry of Education and Science of Ukraine "On Approval of the Procedure for Inclusive Groups Inclusion in Pre-School Institutions" (2015) and the Letter of the Ministry of Education and Science of Ukraine "On the Procedure for Inclusive Groups Inclusion in Pre-School Institutions" (2015), the work of admitting children with special educational needs to these groups was regulated. Today, the system 
of pre-school establishments for children with special educational needs is made up of special pre-school educational institutions (nursery-kindergartens) of the combined type; nursery-compensating kindergartens (special and sanatorium) for children from two to six (seven) years, who need correction of physical and (or) mental development, long-term treatment and rehabilitation; educational institutions with special and inclusive groups.

In order to ensure the right of children with special educational needs aged from two to eighteen to receive pre-school and general secondary education, including education in vocational schools, the government made a decision on the establishment of Inclusive-Resource Centres on the basis of existing PMPC (psycho-medico-psychological counselling) or schools with inclusive classes, or basic schools, and approved it in the Resolution "On Approval of the Regulations on the Inclusion and Resource Centre" (2017). Centres carry out a comprehensive psychological and pedagogical assessment of the development of a child with special educational needs, provide them with psychological and pedagogical assistance and secure a systemic qualified support. Centre specialists will cooperate with educational institutions helping them in organizing inclusive education and equipping the educational environment. It is the resource centres that will provide schools with recommendations for the special educational needs of the pupils and will correct individual programs of their development during period of studying and will conduct corrective lessons. The centres will also be assigned tasks of education. For example, to explain to the society the expediency of introducing inclusive education, to spread the idea of tolerant attitude towards children with special educational needs, etc. Unification of terminology in legislative acts of Ukraine takes place during this period (Zakon 2017).

At the fifth stage, the deinstitutionalisation of education for children with violations of physical, mental, intellectual development was started in accordance with the Decree of the Cabinet of Ministers of Ukraine "On the National Strategy for the Reforming of the Institutional Care and of the Upbringing of Children for the years 2017-2026 and the Action Plan for Implementation of Its Stage I" (2017). The implementation of the approved documents will enable, by 2019, to develop and adopt normative legal acts and organize the methodological support necessary for reforming the system of institutional care and upbringing of children; to analyze the existing network of institutions for institutional care of children, to evaluate the provision of children's rights in each region and to approve regional plans for the reforming of the system of institutional care and upbringing of children; to form regional teams and prepare them for implementation of the strategy of reforms; to develop curricula for the training and retraining of specialists, in particular, those working with disabled children; to develop criteria for monitoring the process of reforming the system of institutional care and upbringing of children; to attract investments for implementation of the reform of 
the system of institutional care and upbringing of children. These documents are aimed at replacing the system of institutional care and upbringing of children with the system that provides for the care and upbringing of a child in the family or close to the family environment. At present, in Ukraine there are 751 institutions of the institutional care of children, of which 39 institutions are under the control of the Ministry of Health of Ukraine, 132 institutions (boarding schools, centers for social and psychological rehabilitation of children, shelters for children) are under the control of the Ministry of Social Policy of Ukraine; 580 institutions of different types are under the control of the Ministry of Education and Science of Ukraine. In addition, there are institutions for institutional care of children formed by public associations.

Recognizing the indisputable need for reforming the education for children with violations of physical, mental, intellectual development and the expediency of using this foreign experience, it is important to note the need to involve the achievements of domestic science and practice in this process, since the main goal - the education and upbringing of this category of children - is often best achieved at the progressive development of education. Borrowings are expedient only if they are more effective than the domestic experience. From this perspective, one of the options for the possible embodiment of an inclusive idea in the Ukrainian education is the proposed model for the integration of children with violations of physical, mental, intellectual development in the general education space (Malofeev 2008, pp. 71-78; Shmatko 1999, pp. 41-46; Kuzava 2013, pp. 380-387). The first model is a constant full integration. It involves the education of a child with peculiarities of psychophysical development on equal terms with able-bodied children in some preschool groups and classes. Full integration can be effective for the children whose level corresponds to the level of psychophysical and linguistic development or is close to the age standard of healthy children. The second model is a permanent incomplete integration. It can be effective for those children whose level of mental development is lower than the age standard. This group of children needs systematic corrective assistance, but, at the same time, they are able to study some subjects together with able-bodied children of their age and spend most of their extracurricular time with them. The permanent incomplete integration can be organized in all preschool and general educational institutions. Children with disabilities combine with able-bodied children in one preschool group ("special") or one class ("flexible"). The third model is a permanent partial integration. It is offered for a group of children who are able to master only a small part of the necessary skills at the level of able-bodied children of their age, to spend part of curricular and extracurricular time with them. The need for such a model is seen in the possibility of expanding the communication and interaction of children with disabilities with able-bodied children of their age. The fourth model is a systematic 
temporary integration. It makes it possible to minimize the communication of children with disabilities and able-bodied children of their age. The model involves holding joint events at least twice a month, preferably of an educational nature. The model can be implemented in pre-school educational institutions of the combined type and in mass schools where there are special groups (classes). The fifth model is an episodic integration. It focuses on special preschool and school institutions that are limited in the ability to conduct purposeful work with able-bodied children in upbringing and education, and provides for the minimum interaction of children with severe mental and physical impairments with their peers in remedial institutions. At the episodic integration, pupils of special educational institutions study separately all the time, and only sometimes they are united with children of general educational institutions for some time (Malofeev 2008, pp. 71-78; Shmatko 1999, pp. 41-46; Kuzava 2013, pp. 380-387).

Not all of these models can be implemented in the general educational environment, and therefore it is expedient not only to preserve some of the traditional institutions of special education, as additional ones with respect to the general education institutions, but also to improve them.

\section{CONCLUSIONS}

In today's conditions of socio-economic development of Ukraine it is problematic to ensure the full development of inclusive education. It is not always possible to implement European standards for the development of social processes to the full mainly for financial reasons. Ukraine is able to find exits from the most difficult situations and solve difficult tasks, but there is a risk of changing the traditional domestic education system significantly without building a competitive innovation education, common for the children with disabilities and able-bodied children. Only careful actions, their gradualness, the reliance on the unique experience gained by domestic scientists and practitioners can contribute to the success of the development of inclusive education. In addition, when implementing the inclusive idea, whose positivity is undeniable, it should be borne in mind that inclusion should not replace the system of education of children of this category on the whole. This is just one of the forms that should exist alongside others - alongside traditional forms that have not lost their significance. A child with violations of physical, mental, intellectual development should be able to choose to exercise his right to education in any type of educational institution and to receive the necessary specialized assistance in this respect. 


\section{REFERENCES}

Chepil, M. (2014). Pedahohichna personolohiia Halychyny mizhvoiennoho periodu: istoriohrafiia problemy [Pedagogical personology of Galicia between the war period: historiography of the problem]. Pedahohichna teoriia i praktyka $v$ konteksti intehratsiinykh protsesiv [Pedagogical theory and practice in the context of integration processes], 1 .

Holova, N. (2012). Suchasnyi stan ta perspektyvnyi rozvytok systemy spetsialnoi osvity osib z obmezhenymy mozhlyvostiamy [The current state and perspective development of the system of special education for people with disabilities]. Pedahohichni nauky [Pedagogical Sciences], 62.

Kolupayeva, A. (2009). Inkliuzyvna osvita: realii ta perspektyvy: monohrafiia [Inclusive Education: Realities and Perspectives: Monograph]. Kyiv: Sammit-Knyha.

Kuzava, I. (2013). Modeli rozvytku inkliuzyvnoi osvity: teoretychnyi aspekt [Models of inclusive education development: The theoretical aspect]. Pedahohichni nauky: teoriia, istoriia, innovatsiini tekhnolohi [Pedagogical Sciences: Theory, History and Innovation Technology], 27.

Malofeev, N. (2008). Bazovyie modeli integrirovannogo obucheniya [Basic models of integrated learning]. Defektologiya [Defectology], 1, 71-78.

Natsionalna dopovid pro stan i perspektyvy rozvytku osvity $v$ Ukraini [National report on the state and prospects of education in Ukraine] (2016). Kyiv: Vydavnytstvo Pedahohichna dumka.

Pokas, V. (1999). Sotsialno-pedahohichni osnovy stanovlennia ta rozvytku zahalnoosvitnikh shkilinternativ v Ukraini [Socio-Pedagogical Bases of the Formation and Development of GeneralEducation Boarding Schools in Ukraine]. Kyiv: Instytut APN.

Shmatko, N. (1999). Dlya kogo mozhet byit effektivnyim integrirovannoe obuchenie [For whom integrated training can be effective]. Defektologiya [Defectology], 1, 41-46.

Suprun, M. (2005). Korektsiine navchannia uchniv dopomizhnykh zakladiv osvity: vytoky, stanovlennia ta rozvytok (druha polovyna XIX - persha polovyna XX st.) [Correctional Study of Students of Auxiliary Educational Institutions: Origins, Formation and Development (the Second Half of the $19^{\text {th }}$ and the First Half of the $20^{\text {th }}$ Century)]. Kyiv: Vydavnytstvo PALYVODA.

Yarmachenko, M. (1975). Istoriia surdopedahohiky [History of Surdopedagogy]. Kyiv: Vydavnytstvo Vyshcha shkola.

Zakon (2017). Zakon «Pro vnesennia zmin do deiakykh zakonodavchykh aktiv Ukrainy» vid № 2249-VII 19.12.17. [The Law “On Amendments to Certain Legislative Acts of Ukraine”]. Mode of access: https://zakon.rada.gov.ua/laws/show/2249-19 (access: 20.04.2018).

Zasenko, V. (2004). Stan i priorytety rozvytku spetsialnoi osvity. Suchasni tendentsii rozvytku spetsialnoi osvity [Status and Priorities of Special Education Development]. Kyiv: Vydavnytstvo Naukovyi svit. 